\title{
Studies of In Vitro Synthesis of Heterogenic Hemoglobins*
}

\author{
J. David Heywood, $†$ Myron Karon, and Sherman Weissman \\ (From the Medicine Branch and Metabolism Service, National Cancer Institute, \\ Bethesda, Md.)
}

In addition to the difficulties caused by increased hemolysis of peripheral red cells, patients with various hemoglobinopathies suffer from a limited capacity to synthesize hemoglobin (1). In recent years a great deal of investigative effort, especially in the field of microbial genetics, has been devoted to the nature of the inductionrepression processes that control the rate of synthesis of specific proteins $(2,3)$. Relatively little information, however, is available concerning the quantitative effects of a structural gene mutation on the synthesis of a given protein.

As an initial approach to this problem, studies of the relationship between the synthetic rates of heterogenic hemoglobins and the amounts of such hemoglobins in the peripheral blood were undertaken. The results indicate that the two hemoglobins are synthesized at different rates. Furthermore, in the cases studied here, the synthetic rates were proportional to the ratio of the amounts of the two hemoglobins in the peripheral blood. These heterogenic hemoglobin synthesizing systems were equally stable under a wide variety of metabolic conditions.

\section{Methods}

Six patients with hemoglobinopathies were studied: two with SC hemoglobin, two with SA hemoglobin, one with CA hemoglobin, and one with DA hemoglobin. All patients were well at the time of the study except one (D.M.) with SC disease who was in a painful crisis. The hemoglobin types $\mathrm{S}, \mathrm{C}$, and $\mathrm{A}$ were verified by paper electrophoresis in barbital buffer at $\mathrm{pH} 8.6$ (4) and the D hemoglobin by agar gel electrophoresis (5). An attempt was made to induce marrow erythroid stimulation in four of the subjects by phlebotomy of $1 \mathrm{U}$ of blood daily for 2 consecutive days.

For each study approximately $50 \mathrm{ml}$ of peripheral blood was obtained by venipuncture and collected directly into tubes containing about $1 \mathrm{mg}$ of heparin for

\footnotetext{
* Submitted for publication January 10, 1964 ; accepted August 27, 1964.

$\dagger$ Present address: Department of Medicine, University of Washington Medical School, Seattle, Wash.
}

each $5 \mathrm{ml}$ of blood. Concomitantly, 5 to $10 \mathrm{ml}$ of marrow was obtained from the posterior iliac crest by aspiration through a Rosenthal needle with a $20-$ to $30-\mathrm{ml}$ syringe and immediately placed in a tube containing 5 to $10 \mathrm{mg}$ of heparin. All tubes were in ice. The heparinized cells were separated from the plasma by centrifugation at $1,500 \mathrm{rpm}$ for 15 minutes at $5^{\circ} \mathrm{C}$. The cells were then washed once in 3 vol of Borsook's (6) modified Krebs-Henseleit solution without bicarbonate. From the loosely packed washed red cells the top 2 to 3 $\mathrm{ml}$ (7) was aspirated and resuspended in the incubation media. For marrow, the entire washed cell preparation, with no attempt at enrichment with young cells, was evenly mixed and then resuspended in the media. There was no clotting or clumping of the marrow cells or reticulocytes when prepared in this manner.

One-half to $1.0 \mathrm{ml}$ of cells was incubated in a modified Krebs-Henseleit solution to which had been added a complete amino acid mixture minus leucine in the proportions described by Borsook, Fischer, and Keighley (6) : dextrose, $1 \mathrm{mg}$ per $\mathrm{ml}$; ferrous ammonium sulfate, $0.18 \mu$ mole per $\mathrm{ml}$; heparin, $0.1 \mathrm{mg}$ per $\mathrm{ml}$; penicillin, $50 \mathrm{U}$ per $\mathrm{ml}$; and 0.5 to $1 \mu \mathrm{c}$ of uniformly labeled $\mathrm{C}^{14}$-L-leucine, $246 \mathrm{mc}$ per mmole. ${ }^{1}$ The total incubation volume was $4 \pm 0.5 \mathrm{ml}$. Incubations were carried out in 25-ml Ehrlenmeyer flasks under $95 \% \mathrm{O}_{2}$ and $5 \% \mathrm{CO}_{2}$ at $37^{\circ} \mathrm{C}$ in a Dubnoff metabolic shaker for 4 hours, or as otherwise indicated.

Preliminary experiments had indicated that there was no difference in the specific activities and specific activity ratios of the two hemoglobins when the cells were incubated either under $95 \%$ air and $5 \% \quad \mathrm{CO}_{2}$ or $95 \% \mathrm{O}_{2}$ and $5 \% \mathrm{CO}_{2}$. Incubation conditions were varied experimentally as indicated under Results.

Reactions were stopped by chilling the flasks. The cells were washed two times with 10 vol of cold $0.02 \mathrm{M}$ $\mathrm{C}^{12}$ leucine in normal saline, then rewashed with cold normal saline. The cells were lysed with 4 vol of cold distilled water and $1 \mathrm{vol}$ of toluene, and shaken on a Vortex mixer. After storage overnight at $4^{\circ} \mathrm{C}$, the stroma were removed from the lysate by centrifuging 30 minutes at $15,000 \times g$ at $4^{\circ} \mathrm{C}$. Carbon monoxide was passed over the lysate for 2 to 3 minutes with swirling to convert the hemoglobin to CO-hemoglobin. The CO-hemoglobin solution was then dialyzed against three changes of 30 to 50 vol of $0.01 \mathrm{M}$ sodium phosphate, $\mathrm{pH}$ 7.0 , saturated with carbon monoxide, and then stored at $4^{\circ} \mathrm{C}$ until chromatographed.

\footnotetext{
1 New England Nuclear Corp., Boston, Mass.
} 
The major hemoglobin components were separated by column chromatography on the cation exchange resin carboxymethylcellulose (CM-cellulose), ${ }^{2} 0.65$ to $0.67 \mathrm{mEq}$ per $\mathrm{g}$, employing a modification of the method of Huisman, Martis, and Dozy (8). Sixty mg of CO-hemoglobin was applied to a $16-$ to $18-\mathrm{cm} \times 0.8-\mathrm{cm}$ column. The column was then washed with 50 to $100 \mathrm{ml}$ of 0.01 $\mathrm{M}$ sodium phosphate, $\mathrm{pH} 7.0$, to remove the nonhemoglobin protein and small amounts of unabsorbed CO-hemoglobin. Elution was then begun with a linear gradient of $0.01 \mathrm{M}$ sodium phosphate, $\mathrm{pH} 7.15$ to 7.2 , in the first chamber into which was fed $0.01 \mathrm{M}$ sodium phosphate of higher $\mathrm{pH}$ from two end chambers. The apparatus was such that three $1-\mathrm{L}$ chambers of similar dimensions were connected in a linear fashion with the starting buffer in the first chamber and the end buffer in the next two chambers. The end buffer was $\mathrm{pH} 8.0$ for separation of SA and DA samples, and $0.01 \mathrm{M} \mathrm{Na}_{2} \mathrm{HPO}_{4}$ for separation of SC and CA samples. Seven hundred to $750 \mathrm{ml}$ of buffer was in each chamber at the beginning for the SA, $\mathrm{SC}$, and DA separations and $400 \mathrm{ml}$ for the CA separations. Chromatography was performed at $4^{\circ} \mathrm{C}$. The flow rate was between 15 and $30 \mathrm{ml}$ per hour with a pressure head of $50 \mathrm{~cm}$ of buffer. Complete runs required 18 to 36 hours. The accuracy of this method in separating $\mathrm{S}$ from $\mathrm{A}$ hemoglobin, the two closest major components on CM-cellulose chromatography, was checked by separating a known mixture of two parts $\mathrm{S}$ hemoglobin and one part $\mathrm{A}$ hemoglobin. Of the recovered hemoglobin, $62.4 \%$ was in the $\mathrm{S}$ peak and $37.6 \%$ in the A peak. Hemoglobin $\mathrm{C}$ is more widely separated from $S$ or $A$ hemoglobin on the chromatogram, making overlap of the peaks even less likely in the SC and CA separations. $\mathrm{D}$ hemoglobin is eluted at the same $\mathrm{pH}$ as $\mathrm{S}$ hemoglobin from CM-cellulose. In addition, on two occasions, the $\mathrm{S}$ and $\mathrm{A}$ hemoglobins obtained from column chromatography were reconcentrated on CM-cellulose (9), and then each hemoglobin was subjected to electrophoresis on paper at $\mathrm{pH}$ 8.6. The $\mathrm{S}$ hemoglobin papers showed no material in the A hemoglobin region, and vice versa.

Carbon monoxide was bubbled through the tubes and optical density at $412 \mathrm{~m} \mu$ determined on the Beckman DU

2 Bio-Rad Chemicals, Inc., Richmond, Calif. spectrophotometer with cells of $1-\mathrm{cm}$ path length. A pool of each hemoglobin peak was made, optical density was determined, and $1.0 \mathrm{ml}$ was plated on a 2 -inch diameter aluminum planchet and counted on a gas flow $\beta$ counter $^{3}$ with a background of 1 to $2 \mathrm{cpm}$. Counting of serial dilutions on some samples indicated that $1-\mathrm{ml}$ samples were near infinite thinness. Specific activity. was then expressed as net counts per minute per optical density unit at $412 \mathrm{~m} \mu \pm 2 \mathrm{SD}$ of the count rate. The total amount of each hemoglobin synthesized was determined by multiplying the specific activity times the total absorbancy of the peak.

The reliability of this method of expressing the specific activities was corroborated by measuring the proteins by the method of Lowry, Rosebrough, Farr, and Randall (10) and also by precipitating samples of the pooled peaks with $5 \%$ trichloroacetic acid (TCA) and washing the precipitates three times with 5\% TCA, once with $3: 1$ ethanol: ether, and once with ether. The dried precipitates were then dissolved in $0.1 \mathrm{ml}$ of $1.0 \mathrm{~N}$ sodium hydroxide and diluted to $1.0 \mathrm{ml}$ with water. A $0.1-\mathrm{ml}$ sample was counted on planchets in the low background $\beta$ counter, and protein was measured by the Lowry method. Excellent agreement was obtained between the different methods.

\section{Results}

Some hematologic data and the effect of phlebotomy in these subjects are summarized in $\mathrm{Ta}$ ble I. The SC disease subject (R.C.) had only minimal intermittent symptomatology ascribable to his hematologic disease. His hemoglobin was 13.5 to $14.5 \mathrm{~g}$ per $100 \mathrm{ml}$ with a 3 to $4 \%$ reticulocyte count. This is in contrast with the SC disease patient (D.M.), who had suffered frequent severe crises. She was severely anemic and in a painful crisis at the time that her marrow and reticulocytes were initially studied. As anticipated, phlebotomy was well tolerated by the sub-

\footnotetext{
${ }^{3}$ Sharp Laboratories, La Jolla, Calif.
}

TABLE I

Summary of pertinent clinical data

\begin{tabular}{|c|c|c|c|c|c|c|c|}
\hline \multirow[b]{2}{*}{ Patient } & \multirow[b]{2}{*}{ Age } & \multirow[b]{2}{*}{ Sex } & \multirow{2}{*}{$\begin{array}{c}\text { Hemo- } \\
\text { globin } \\
\text { type }\end{array}$} & \multicolumn{2}{|c|}{ Before phlebotomy } & \multicolumn{2}{|c|}{ After phlebotomy } \\
\hline & & & & $\begin{array}{c}\text { Hemo- } \\
\text { globin }\end{array}$ & $\begin{array}{c}\text { Reticulo- } \\
\text { cytes }\end{array}$ & $\begin{array}{l}\text { Hemo- } \\
\text { globin }\end{array}$ & $\begin{array}{c}\text { Reticulo- } \\
\text { cytes }\end{array}$ \\
\hline & & & & $\mathrm{g} / 100 \mathrm{ml}$ & $\%$ & $\mathrm{~g} / 100 \mathrm{ml}$ & $\%$ \\
\hline R.C. & 41 & $\mathrm{M}$ & $\mathrm{SC}$ & 13.3 & 3.2 & 12.6 & 7.5 \\
\hline A.B. & 48 & $\mathrm{M}$ & $\mathrm{SA}$ & 13.6 & 0.7 & 12.0 & 2.1 \\
\hline L.F.* & 25 & $\mathrm{~F}$ & $\mathrm{CA}$ & 12.2 & 1.0 & 10.1 & 4.0 \\
\hline A.L. & 53 & $\mathrm{~F}$ & $\mathrm{SA}$ & 12.6 & 1.1 & 10.7 & 2.5 \\
\hline D.M. & 24 & $\mathrm{~F}$ & $\mathrm{SC}$ & 7.5 & 10.5 & & \\
\hline D.N. & 47 & $\mathrm{M}$ & DA & 16.5 & 0.7 & & \\
\hline
\end{tabular}

* Serum iron was $24 \mu \mathrm{g}$ per $100 \mathrm{ml}$. 

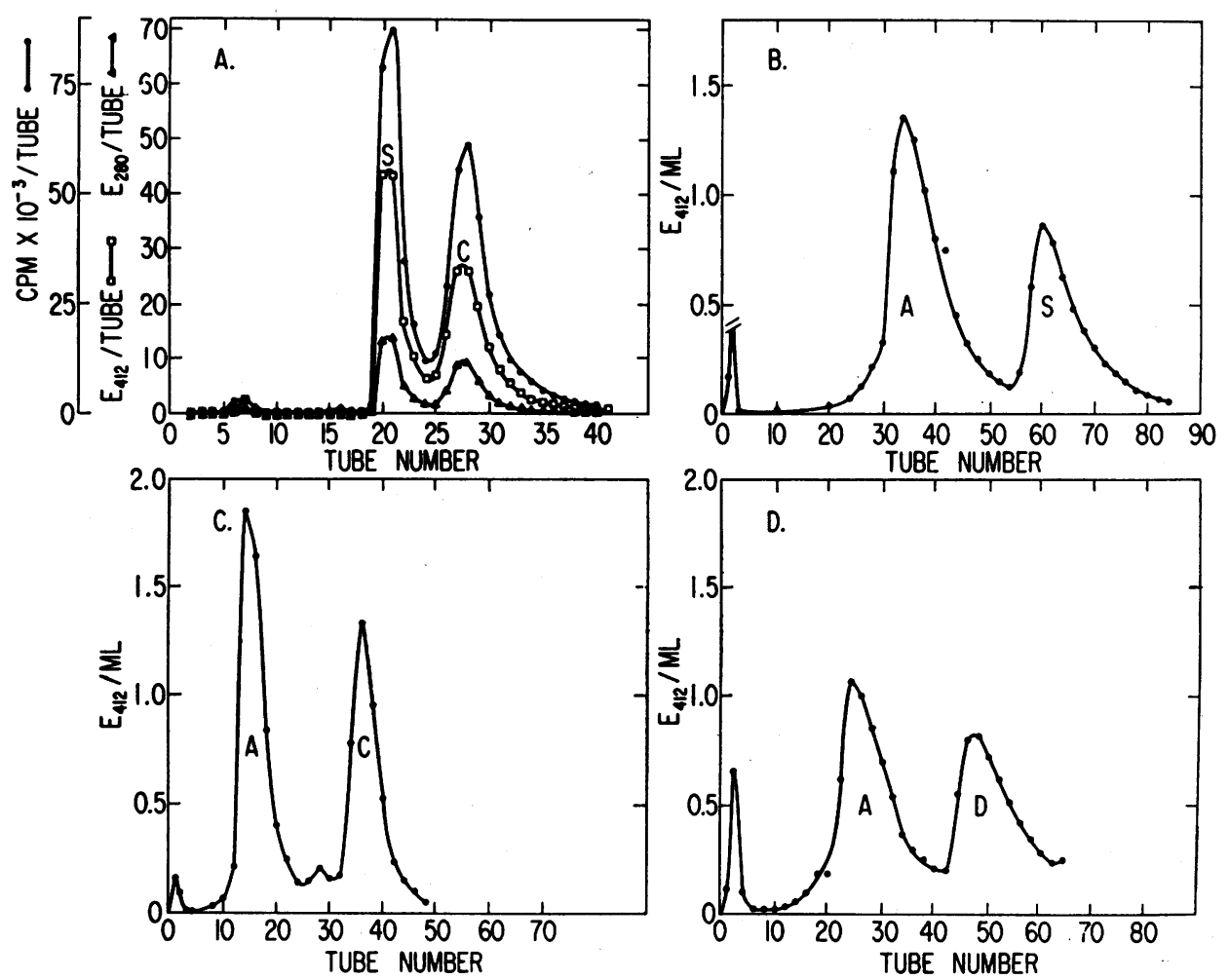

Fig. 1. Representative hemoglobin chromatograms. The radioactivity and the $\mathrm{OD}_{230}$ per tube are also plotted on the SC chromatogram (A). The minor intermediate peak consistently seen on the chromatogram of CA hemoglobin $(C)$ is in the position for $A_{2}$ hemoglobin (8).

jects. The decrease in hemoglobin after phlebotomy varied from 1 to $2 \mathrm{~g}$ per $100 \mathrm{ml}$, with a subsequent 2 - 3 -fold increase in peripheral reticulocyte count. With the use of high specific activity $C^{14}$-L-leucine, reticulocyte counts of 2 to $3 \%$ yielded final specific activities of chromatographically purified hemoglobin solutions of 8 to $16 \mathrm{cpm}$ per optical density unit at $412 \mathrm{~m} \mu$. Five to $10 \%$ reticulocyte counts gave final specific activities of 50 to $130 \mathrm{cpm}$ per optical density unit at 412 $\mathrm{m} \mu$. Marrow suspensions were one to seven times as active as the peripheral blood preparations in incorporating isotope into hemoglobin, indicating an enrichment with young cells in the marrow preparations. The specific activities of the marrow hemoglobin samples appeared inversely proportional to the degree of dilution of the marrow sample with peripheral blood at the time of aspiration, and directly proportional to the degree of erythroid hyperplasia of the marrow as estimated from Wright-stained smears. Four- hour marrow incubations done when the subject's peripheral reticulocyte count was 0.6 to $1.1 \%$ yielded final hemoglobin specific activities of 10 to $40 \mathrm{cpm}$ per optical density unit at $412 \mathrm{~m} \mu$.

Figure 1, A to D, shows typical chromatograms obtained for the separation of SA, SC, CA, and DA hemoglobins, respectively. The radioactivity followed the major hemoglobin peaks closely, as illustrated in Figure 1A. The specific activity of

TABLE II

Reticulocyte counts and corresponding $S$ and $A$ hemoglobin percentages from top and bottom layers of centrifuged peripheral blood; obtained before phlebotomy

\begin{tabular}{clccc}
\hline \hline Patient & $\begin{array}{c}\text { Cell } \\
\text { fraction }\end{array}$ & $\begin{array}{c}\text { Retic- } \\
\text { ulocyte } \\
\text { count }\end{array}$ & $\begin{array}{c}\% \mathrm{~S} \\
\text { hemo- } \\
\text { globin }\end{array}$ & $\begin{array}{c}\% \mathrm{~A} \\
\text { hemo- } \\
\text { globin }\end{array}$ \\
\hline & & $\%$ & & \\
A.B. & Top & $\mathbf{0 . 2 5}$ & 42.3 & 57.7 \\
& Bottom & 0.08 & 44.2 & 55.8 \\
A.L. & Top & 0.9 & 34.8 & 65.2 \\
& Bottom & 0.4 & 33.4 & 66.6 \\
\hline
\end{tabular}


TABLE III

Marrow hemoglobin synthetic ratios compared with ratios of hemoglobins present in the marrow preparations*

\begin{tabular}{|c|c|c|c|c|c|c|c|c|c|c|}
\hline \multirow[b]{2}{*}{ Patient } & \multicolumn{4}{|c|}{ Specific activity† } & \multicolumn{4}{|c|}{ Total recovery, OD } & \multirow{2}{*}{$\begin{array}{c}\text { Synthetic } \\
\text { ratiof }\end{array}$} & \multirow{2}{*}{$\begin{array}{l}\text { Blood } \\
\text { ratio§ }\end{array}$} \\
\hline & $\mathrm{s}$ & $\mathrm{C}$ & $\mathrm{D}$ & A & $\mathrm{s}$ & $\mathrm{C}$ & $\mathrm{D}$ & $\mathbf{A}$ & & \\
\hline R.C. & $65 \pm 1.6$ & $67 \pm 1.8$ & & & 222 & 223 & & & 0.97 & 1.00 \\
\hline D.M. & $143 \pm 1.0$ & $147 \pm 1.2$ & & & 261 & 257 & & & 0.99 & 1.01 \\
\hline A.B. & $24.9 \pm 0.8$ & & & $24.2 \pm 0.7$ & 192 & & & 242 & 0.82 & 0.80 \\
\hline A.L. & $12.0 \pm 0.7$ & & & $12.0 \pm 0.9$ & 192 & & & 225 & 0.85 & 0.85 \\
\hline L.F. & & $40 \pm 1.6$ & & $41 \pm 1.1$ & & 148 & & 184 & 0.78 & 0.80 \\
\hline D.N. & & & $11 \pm 1.0$ & $10.0 \pm 0.8$ & & & 157 & 198 & 0.87 & 0.79 \\
\hline
\end{tabular}

* All values were obtained from marrow incubations done before phlebotomy and in the complete media, under $95 \%$ $\mathrm{O}_{2}$ and $5 \% \mathrm{CO}_{2}$. Samples from R.C. and D.M. were from 90 -minute incubations, and the remainder from 4-hour incubations.

$\dagger \mathrm{cpm} \pm 2 \mathrm{SD}$ of the count rate/OD 412 .

I Synthetic ratio (e.g., for $\mathrm{SC}$ incubation) $=$ specific activity $(\mathrm{S}) \times$ total recovery $(\mathrm{S}) \mathrm{OD} /$ specific activity (C) $X$ total recovery $(\mathrm{C}) \mathrm{OD}$.

$\S$ Blood ratio (e.g., for SC patients) = total recovery (S) OD/total recovery (C) OD.

hemoglobin was slightly greater at the extremes of the peaks than at the center, as observed by others (11). The absolute amount of this material was so small, however, that it did not significantly affect the specific activity of the pool of the entire peak. An average of $76 \%$ (range, 64 to $100 \%$ ) of the CO-hemoglobin and 58\% (range, 39 to $90 \%$ ) of the radioactivity applied to the column was recovered in the major hemoglobin peaks. Although total hemoglobin recovery was variable, the ratio of the two recovered hemoglobins in multiple runs was always the same. The variability in total hemoglobin recovery depended chiefly on the amount of CO-hemoglobin that did not absorb to the CM-cellulose at the time of application. A small amount of denatured hemoglobin also was not eluted from the column by the end of the run. The lower percentage recovery of radioactivity in the major hemoglobin components is accounted for by the incorporation of label into the nonhemoglobin protein peak, which is not adsorbed to the resin, and by a small but variable amount of free $\mathrm{C}^{\mathbf{1 4}}$-L-leucine that remained in the hemoglobin solution after preparing it for the column.

After preparing the cells of the two SA patients in the manner described, there was some reticulocyte enrichment in the top layer. Chromatographic analysis of the hemoglobin in the top and bottom layers of cells revealed no significant difference in the percentage of $\mathrm{S}$ and $\mathrm{A}$ hemoglobin, however, as shown in Table II.

No attempt was made to isolate the minor hemoglobin fractions $F$ and $A_{2}$ from the major components. The normal low levels of these components would not alter measurably the specific activities and determinations of total synthesis of the major hemoglobin fractions.

Hemoglobin synthetic rates vs. marrow hemoglobin ratios. Table III illustrates that in these subjects the synthetic rates of the hemoglobins were proportional to the ratio of the two hemoglobins found in the marrow. This proportionality is indicated by the equal specific activities of the two hemoglobins from any incubation, that is, with SA cells as an example, in any incubation of heterogenic hemoglobins $(\mathrm{Hgb})$, total $\mathrm{Hgb} \mathrm{S}$ synthesized/total $\mathrm{Hgb}$ A synthesized $=$ (specific activity $\mathrm{Hgb} \mathrm{S} \times$ total $\mathrm{Hgb} \mathrm{S}$ recovered)/(specific activity $\mathrm{Hgb} \mathrm{A} \times$ total $\mathrm{Hgb} \mathrm{A}$

TABLE IV

Hemoglobin synthetic ratios: marrow vs. reticulocyte incubations

\begin{tabular}{|c|c|c|c|c|c|c|}
\hline \multirow[b]{2}{*}{ Patient } & \multirow[b]{2}{*}{ Cells* } & \multicolumn{4}{|c|}{ Specific activity $\dagger$} & \multirow{2}{*}{$\begin{array}{l}\text { Ratio of } \\
\text { specific } \\
\text { activities }\end{array}$} \\
\hline & & $\mathrm{S}$ & & $\mathrm{C}$ & A & \\
\hline \multirow[t]{2}{*}{ R.C. $\S$} & $\mathbf{R}$ & $50.3 \pm 0.6$ & 53 & \pm 1.1 & & $0.95 \pm 0.03$ \\
\hline & $\mathbf{M}$ & $65 \pm 1.6$ & 67 & \pm 1.8 & & $0.97 \pm 0.05$ \\
\hline \multirow{2}{*}{ D.M. } & $\mathbf{R}$ & $121.6 \pm 0.8$ & 132 & \pm 1.1 & & $0.92 \pm 0.01$ \\
\hline & M & $265 \pm 2.0$ & 279 & \pm 2.0 & & $0.95 \pm 0.01$ \\
\hline \multirow[t]{2}{*}{ A.B. } & $\mathbf{R}$ & $8.5 \pm 0.6$ & & & $8.4 \pm 0.5$ & $1.01 \pm 0.13$ \\
\hline & $\mathbf{M}$ & $58 \pm 1.1$ & & & $57.0 \pm 0.9$ & $1.02 \pm 0.04$ \\
\hline \multirow[t]{2}{*}{ A.L. } & $\mathbf{R}$ & $16 \pm 1.3$ & & & $17 \pm 1.2$ & $0.94 \pm 0.14$ \\
\hline & $\mathbf{M}$ & $31 \pm 1.0$ & & & $30.9 \pm 0.8$ & $1.00 \pm 0.06$ \\
\hline \multirow[t]{2}{*}{ L.F. } & $\mathbf{R}$ & & 11. & $2 \pm 0.7$ & $12.4 \pm 0.7$ & $0.90 \pm 0.11$ \\
\hline & $\mathbf{M}$ & & 36. & $8 \pm 0.8$ & $36 \pm 1.1$ & $1.02 \pm 0.05$ \\
\hline
\end{tabular}

$* \mathrm{R}=$ reticulocytes $; \mathrm{M}=$ marrow.

$+\mathrm{cpm} \pm 2 \mathrm{SD} / \mathrm{OD}$,

Ratios are $\mathrm{S} / \mathrm{C}, \mathrm{S} / \mathrm{A}$, and $\mathrm{C} / \mathrm{A} \pm 2 \mathrm{SD}$.

The values for R.C. were from incubations done before phlebotomy, and those for A.B., A.L., and L.F. from incubations after phlebotomy. D.M. was not phlebotomized. 
TABLE V

Effect of incubation time on hemoglobin specific activity ratios*

\begin{tabular}{|c|c|c|c|c|c|c|}
\hline \multirow[b]{2}{*}{ Patient } & \multirow{2}{*}{$\underset{\substack{\text { gemo- } \\
\text { type }}}{\text { Hemin }}$} & \multirow[b]{2}{*}{ Time } & \multicolumn{3}{|c|}{ Specific activity $\dagger$} & \multirow{2}{*}{$\begin{array}{l}\text { Ratio of specific } \\
\text { activities } f\end{array}$} \\
\hline & & & $\mathrm{s}$ & $\mathrm{C}$ & A & \\
\hline & & hrs & & & & \\
\hline A.B. & $\mathrm{SA}$ & $\begin{array}{l}0.5 \\
4 \\
6.5\end{array}$ & $\begin{array}{r}3.4 \pm 0.4 \\
24.9 \pm 0.8 \\
58 \pm 1.1\end{array}$ & & $\begin{array}{r}3.3 \pm 0.3 \\
24.2 \pm 0.7 \\
57.0 \pm 0.9\end{array}$ & $\begin{array}{l}1.03 \pm 0.21 \\
1.03 \pm 0.06 \\
1.02 \pm 0.04\end{array}$ \\
\hline A.L. & SA & $\begin{array}{l}4 \\
1.5 \S\end{array}$ & $\begin{array}{l}31 \pm 1.0 \\
13.3 \pm 0.5\end{array}$ & & $\begin{array}{l}30.9 \pm 0.8 \\
14.4 \pm 0.7\end{array}$ & $\begin{array}{l}1.00 \pm 0.06 \\
0.92 \pm 0.08\end{array}$ \\
\hline L.F. & $\mathrm{CA}$ & $\begin{array}{l}0.5 \\
1.5 \S \\
4\end{array}$ & & $\begin{array}{r}9.2 \pm 0.4 \\
16 \pm 1.1 \\
36.8 \pm 0.8\end{array}$ & $\begin{array}{r}9.0 \pm 0.6 \\
15.4 \pm 0.8 \\
36 \pm 1.1\end{array}$ & $\begin{array}{l}1.02 \pm 0.11 \\
1.04 \pm 0.13 \\
1.02 \pm 0.05\end{array}$ \\
\hline
\end{tabular}

* All values are from marrow incubations under optimal conditions.

$\dagger \mathrm{cpm} \pm 2 \mathrm{SD} / \mathrm{OD}_{412}$.

$\pm S / A$ and $C / A \pm 2 S D$.

$\S$ In these incubations, the cells were incubated 1.5 hours without isotope and then 1.5 hours with isotope.

recovered). Since the specific activity of $\mathrm{S} \mathrm{Hgb}$ = specific activity of $\mathrm{A} \mathrm{Hgb}$, then specific activity $\mathrm{Hgb} \mathrm{S} /$ specific activity $\mathrm{Hgb} \mathrm{A}=1$, and total $\mathrm{Hgb}$ $\mathrm{S}$ synthesized/total $\mathrm{Hgb}$ A synthesized = total recovered $\mathrm{Hgb} \mathrm{S} /$ total recovered $\mathrm{Hgb} \mathrm{A}$. A specific activity ratio deviating significantly from 1 would indicate a disproportion between the amount of each hemoglobin synthesized and that found in the blood.

Bone marrow vs. reticulocyte incubations. The results of bone marrow incubations are compared with reticulocyte incubations under optimal conditions in Table IV. The ratio of the specific activities of the two hemoglobins was nearly 1 for both the marrow and reticulocytes in each individual studied. Therefore, the respective hemo- globins were synthesized at rates proportional to the amounts found in the circulation, even though the absolute synthetic rates for marrow were greater than for reticulocytes, as indicated by the higher marrow hemoglobin specific activities.

Effect of incubation time. The effect of varying the time of incubation on the ratio of the hemoglobin specific activities is presented in Table V. Thirty-minute incubations were compared with 4- to 6.5-hour incubations, and with 1.5 -hour incubations with labeled leucine after a 1.5 -hour preincubation of the cells without isotope. The specific activity ratios were nearly 1 and did not change with time, again illustrating that the synthetic ratio was equal to the peripheral blood ratio of hemoglobins.

TABLE VI

Effect of erythroid stimulation (phlebotomy) on the marrow synthesis of heterogenic hemoglobins*

\begin{tabular}{|c|c|c|c|c|c|c|}
\hline \multirow[b]{2}{*}{ Patient } & \multirow{2}{*}{$\begin{array}{l}\text { Before or } \\
\text { after } \\
\text { phlebotomy }\end{array}$} & \multicolumn{4}{|c|}{ Specific activity $\dagger$} & \multirow{2}{*}{$\begin{array}{c}\text { Ratio of specific } \\
\text { activitiesf }\end{array}$} \\
\hline & & $\mathrm{s}$ & & C & A & \\
\hline R.C. & $\begin{array}{l}\text { Before } \\
\text { After }\end{array}$ & $\begin{array}{l}65 \pm 1.6 \\
67 \pm 1.0\end{array}$ & $\begin{array}{l}67 \\
70\end{array}$ & $\begin{array}{l} \pm 1.8 \\
\pm 1.0\end{array}$ & & $\begin{array}{l}0.97 \pm 0.05 \\
0.96 \pm 0.03\end{array}$ \\
\hline A.B. & $\begin{array}{l}\text { Before } \\
\text { After }\end{array}$ & $\begin{array}{l}24.9 \pm 0.8 \\
58 \pm 1.1\end{array}$ & & & $\begin{array}{l}24.2 \pm 0.7 \\
57.0 \pm 0.9\end{array}$ & $\begin{array}{l}1.03 \pm 0.06 \\
1.02 \pm 0.04\end{array}$ \\
\hline A.L. & $\begin{array}{l}\text { Before } \\
\text { After }\end{array}$ & $\begin{array}{r}12.0 \pm 0.7 \\
31 \pm 1.0\end{array}$ & & & $\begin{array}{l}12.0 \pm 0.9 \\
30.9 \pm 0.8\end{array}$ & $\begin{array}{l}1.00 \pm 0.13 \\
1.00 \pm 0.06\end{array}$ \\
\hline L.F. & $\begin{array}{l}\text { Before } \\
\text { After }\end{array}$ & & $\begin{array}{l}40 \\
36.8\end{array}$ & $\begin{array}{l} \pm 1.6 \\
\pm 0.8\end{array}$ & $\begin{array}{l}41 \\
36\end{array}$ & $\begin{array}{l}0.98 \pm 0.07 \\
1.02 \pm 0.05\end{array}$ \\
\hline
\end{tabular}

* All incubations were done under optimal conditions. Those from subject R.C. were for 90 minutes; the postphlebotomy incubation of cells from A.B. was for 6.5 hours; all others were for 4 hours. Postphlebotomy incubations were 5 to 7 days after phlebotomy.

$+\mathrm{cpm} \pm 2 \mathrm{SD} / \mathrm{OD}_{412}$.

$\pm S / C, S / A$, and $C / A \pm 2 S D$. 
IN VITRO SYNTHESIS OF HETEROGENIC HEMOGLOBINS

TABLE VII

Effect of hypoxia on the marrow synthesis of heterogenic hemoglobins*

\begin{tabular}{|c|c|c|c|c|c|c|c|}
\hline \multirow[b]{2}{*}{ Patient } & \multirow{2}{*}{$\begin{array}{l}\text { Atmos- } \\
\text { phere }\end{array}$} & \multicolumn{5}{|c|}{ Specific activity $\dagger$} & \multirow{2}{*}{$\begin{array}{c}\text { Ratio of } \\
\text { specific activities }\end{array}$} \\
\hline & & & $\mathrm{s}$ & C & $\mathrm{D}$ & A & \\
\hline R.C. & $\begin{array}{l}\mathrm{O}_{2} \\
\mathrm{~N}_{2}\end{array}$ & $\begin{array}{l}65 \\
79\end{array}$ & $\begin{array}{l} \pm 1.6 \\
\pm 1.5\end{array}$ & $\begin{array}{l}67 \pm 1.8 \\
85 \pm 1.6\end{array}$ & & & $\begin{array}{l}0.97 \pm 0.05 \\
0.93 \pm 0.04\end{array}$ \\
\hline D.M. & $\begin{array}{l}\mathrm{O}_{2} \\
\mathrm{~N}_{2}\end{array}$ & $\begin{array}{l}143 \\
150\end{array}$ & $\begin{array}{l} \pm 1.0 \\
\pm 1.0\end{array}$ & $\begin{array}{l}147 \pm 1.2 \\
155 \pm 1.0\end{array}$ & & & $\begin{array}{l}0.97 \pm 0.01 \\
0.97 \pm 0.01\end{array}$ \\
\hline A.B. & $\begin{array}{l}\mathrm{O}_{2} \\
\mathrm{~N}_{2}\end{array}$ & 24. & $\begin{array}{l}9 \pm 0.8 \\
\pm 1.2\end{array}$ & & & $\begin{array}{l}24.2 \pm 0.7 \\
30.8 \pm 0.8\end{array}$ & $\begin{array}{l}1.03 \pm 0.06 \\
1.07 \pm 0.07\end{array}$ \\
\hline A.L. & $\begin{array}{l}\mathrm{O}_{2} \\
\mathrm{~N}_{2}\end{array}$ & 12. & $\begin{array}{l}0 \pm 0.7 \\
3 \pm 0.9\end{array}$ & & & $\begin{array}{l}12.0 \pm 0.9 \\
13.2 \pm 0.9\end{array}$ & $\begin{array}{l}1.00 \pm 0.13 \\
0.99 \pm 0.13\end{array}$ \\
\hline L.F. & $\begin{array}{l}\mathrm{O}_{2} \\
\mathrm{~N}_{2}\end{array}$ & & & $\begin{array}{l}40 \pm 1.6 \\
39 \pm 1.2\end{array}$ & & $\begin{array}{ll}41 & \pm 1.1 \\
37 & \pm 1.2\end{array}$ & $\begin{array}{l}0.98 \pm 0.07 \\
1.05 \pm 0.07\end{array}$ \\
\hline D.N. & $\begin{array}{l}\mathrm{O}_{2} \\
\mathrm{~N}_{2}\end{array}$ & & & & $\begin{array}{r}11 \pm 1.0 \\
8 \pm 1.0\end{array}$ & $\begin{array}{r}10.0 \pm 0.8 \\
7.9 \pm 0.6\end{array}$ & $\begin{array}{l}1.10 \pm 0.19 \\
1.01 \pm 0.20\end{array}$ \\
\hline
\end{tabular}

* Incubations of cells from R.C. and D.M. were for 90 minutes; the remainder for 4 hours. $\dagger \mathrm{cpm} \pm 2 \mathrm{SD} / \mathrm{OD}_{412}$.

$\ddagger \mathrm{S} / \mathrm{C}, \mathrm{S} / \mathrm{A}, \mathrm{C} / \mathrm{A}$, and $\mathrm{D} / \mathrm{A} \pm 2 \mathrm{SD}$.

Effect of erythroid stimulation. Table VI illustrates that erythroid stimulation produced by phlebotomy of four of the subjects did not change the relative synthetic rates of the hemoglobins. Erythroid stimulation was evidenced by the peripheral reticulocytosis, erythroid hyperplasia seen on the marrow smears, and the higher specific activities of the hemoglobins obtained from the postphlebotomy sample incubations. The specific activity ratios were the same before and after phlebotomy. Thus, the ratio of the amounts of the two hemoglobins synthesized was not altered in response to changes in the absolute synthetic rate of each.
Effect of hypoxia. When the cells were incubated under an atmosphere of 95\% $\mathrm{N}_{2}$ and 5\% $\mathrm{CO}_{2}$, severe hypoxia was produced, as evidenced by the markedly cyanotic appearance of the incubation mixture. Under these conditions, again there was no change in the ratio of specific activities for the two hemoglobins being synthesized compared with controls incubated under 95\% $\mathrm{O}_{2}$ and $5 \% \mathrm{CO}_{2}$, as shown in Table VII. Moreover, total hemoglobin synthesis was not suppressed under these conditions as shown by the nearly equal specific activities of the controls versus the hypoxic samples. Therefore, the two hemoglobin synthesizing systems in each instance as stud-

TABLE VIII

Effect of absence of glucose in media on the synthesis of heterogenic hemoglobins*

\begin{tabular}{|c|c|c|c|c|c|c|c|}
\hline \multirow[b]{2}{*}{ Patient } & \multirow[b]{2}{*}{ Cells } & \multicolumn{4}{|c|}{ Specific activity $\dagger$} & \multicolumn{2}{|c|}{ Ratio of specific activities } \\
\hline & & $\mathrm{s}$ & & C & $\mathrm{A}$ & Control & -Glucose \\
\hline R.C. & $\begin{array}{l}\text { Marrow } \\
\text { Marrow } \\
\text { Retics } \\
\text { Retics }\end{array}$ & $\begin{array}{l}65 \pm 1.6 \\
44 \pm 1.4 \\
16.8 \pm 0.7 \\
10.3 \pm 0.8\end{array}$ & $\begin{array}{l}67 \\
45 \\
18 \\
10.8\end{array}$ & $\begin{array}{l} \pm 1.8 \\
\pm 1.6 \\
\pm 1.0 \\
\pm 0.8\end{array}$ & & $\begin{array}{l}0.97 \pm 0.05 \\
0.93 \pm 0.09\end{array}$ & $\begin{array}{l}0.98 \pm 0.07 \\
0.96 \pm 0.14\end{array}$ \\
\hline D.M. & $\begin{array}{l}\text { Marrow } \\
\text { Marrow } \\
\text { Retics } \\
\text { Retics }\end{array}$ & $\begin{array}{l}143 \pm 1.0 \\
145 \pm 1.2 \\
121.6 \pm 0.8 \\
106 \pm 1.3\end{array}$ & $\begin{array}{l}147 \\
160 \\
132 \\
106\end{array}$ & $\begin{array}{l} \pm 1.2 \\
\pm 2.1 \\
\pm 1.1 \\
\pm 1.2\end{array}$ & & $\begin{array}{l}0.97 \pm 0.01 \\
0.92 \pm 0.02\end{array}$ & $\begin{array}{l}0.91 \pm 0.02 \\
1.00 \pm 0.03\end{array}$ \\
\hline A.L. & $\begin{array}{l}\text { Marrow } \\
\text { Marrow }\end{array}$ & $\begin{array}{l}12.0 \pm 0.9 \\
12.0 \pm 0.9\end{array}$ & & & $\begin{array}{l}12.0 \pm 0.9 \\
10.6 \pm 0.8\end{array}$ & $1.00 \pm 0.13$ & $1.13 \pm 0.17$ \\
\hline
\end{tabular}

* Marrow incubations from R.C. and D.M. were for 90 minutes; the remainder for 4 hours.

$\dagger \mathrm{cpm} \pm 2 \mathrm{SD} / \mathrm{OD}_{412}$.

$\ddagger \mathrm{S} / \mathrm{C}$ and $\mathrm{S} / \mathrm{A} \pm 2 \mathrm{SD}$. 
TABLE IX

Effect of deficiencies of several metabolites on the synthesis of heterogenic hemoglobins

\begin{tabular}{|c|c|c|c|c|c|c|}
\hline \multirow[b]{2}{*}{ Patient } & \multirow[b]{2}{*}{ Cells* } & \multirow[b]{2}{*}{ Media } & \multicolumn{3}{|c|}{ Specific activity $\dagger$} & \multirow{2}{*}{$\begin{array}{c}\text { Ratio of specific } \\
\text { activities } f\end{array}$} \\
\hline & & & $\mathrm{S}$ & $\mathrm{C}$ & A & \\
\hline \multirow[t]{3}{*}{ A.B. } & M & Complete & $24.9 \pm 0.8$ & & $24.2 \pm 0.7$ & $1.03 \pm 0.06$ \\
\hline & $\mathbf{M}$ & - Iron & $25.9 \pm 0.7$ & & $26.1 \pm 0.7$ & $0.99 \pm 0.06$ \\
\hline & $\mathrm{M}$ & 0.1 Amino acid $\S$ & $2.9 \pm 0.6$ & & $2.4 \pm 0.7$ & $1.21 \pm 0.74$ \\
\hline \multirow[t]{7}{*}{ L.F.\| } & M & Complete & & $40 \pm 1.6$ & $41 \pm 1.1$ & $0.97 \pm 0.07$ \\
\hline & M & - Iron & & $28 \pm 1.2$ & $27 \pm 1.0$ & $1.04 \pm 0.08$ \\
\hline & $\mathrm{R}$ & Complete & & $11.2 \pm 0.7$ & $12.4 \pm 0.7$ & $0.90 \pm 0.11$ \\
\hline & $\mathrm{R}$ & $-\mathrm{Mg}^{++}$ & & $11.2 \pm 0.7$ & $12.9 \pm 0.7$ & $0.87 \pm 0.10$ \\
\hline & $\mathrm{R}$ & $-\mathrm{K}^{+}$ & & $9.1 \pm 0.5$ & $10.2 \pm 0.7$ & $0.89 \pm 0.11$ \\
\hline & $\mathrm{R}$ & - Lysine & & $10.2 \pm 0.05$ & $12.7 \pm 0.7$ & $0.80 \pm 0.08$ \\
\hline & $\mathrm{R}$ & 0.1 Amino Acid $\S$ & & $11.5 \pm 0.9$ & $11.9 \pm 0.6$ & $0.97 \pm 0.13$ \\
\hline \multirow[t]{5}{*}{ A.L. } & M & Complete & $12.0 \pm 0.7$ & & $12.0 \pm 0.9$ & $1.00 \pm 0.13$ \\
\hline & M & - Valine & $5.9 \pm 0.6$ & & $5.2 \pm 0.5$ & $1.13 \pm 0.23$ \\
\hline & $\mathrm{R}$ & Complete & $16 \pm 1.3$ & & $17 \pm 1.2$ & $0.94 \pm 0.14$ \\
\hline & $\mathrm{R}$ & $-\mathrm{Mg}^{++}$ & $16.6 \pm 0.9$ & & $18.7 \pm 0.7$ & $0.89 \pm 0.08$ \\
\hline & $\mathrm{R}$ & $-\mathrm{K}^{+}$ & $17 \pm 1.0$ & & $18 \pm 1.0$ & $0.94 \pm 0.11$ \\
\hline
\end{tabular}

* $\mathrm{M}=$ marrow $; \mathrm{R}=$ reticulocytes.

$\dagger \mathrm{cpm} \pm 2 \mathrm{SD} / \mathrm{OD}_{412}$.

$\ddagger \mathrm{S} / \mathrm{A}$ and $\mathrm{C} / \mathrm{A} \pm 2 \mathrm{SD}$.

$\$ 0.1$ amino acid means that all $\mathrm{C}^{12}$-amino acids were present in one-tenth the concentration of the complete media.

\|I This subject was iron deficient, with a serum iron of $24 \mu \mathrm{g}$ per $100 \mathrm{ml}$.

ied here were equally insensitive to hypoxic conditions.

Effect of various metabolite deficiencies. Omission of certain essential metabolites from the incubation media also did not change the hemoglobin specific activity ratios. When glucose, an important energy source (6), was omitted from the media, total hemoglobin synthesis was suppressed in three of five experiments from 12 to $41 \%$ (Table VIII). The relative synthetic rates of the two hemoglobins, however, were unchanged when compared with controls.

Omission of iron from the media of marrow incubations was studied in two instances. Total hemoglobin synthesis was suppressed $30 \%$ by omitting iron from the media of the marrow incubation of the CA hemoglobin subject L.F., who was severely iron deficient, with a serum iron of only $24 \mu \mathrm{g}$ per $100 \mathrm{ml}$. In spite of this, there was no change in the ratio of hemoglobin specific activities when compared with control values (Table IX).

Decreasing the concentration of the $\mathrm{C}^{12}$-amino acids in the media to 0.1 of the concentration in the complete media also did not change the hemoglobin specific activity ratios, although total hemoglobin synthesis was markedly suppressed in one case (A.B.). Omission of the amino acid lysine in one incubation of $\mathrm{CA}$ reticulocytes and of valine from an incubation of SA marrow did not alter the ratio of hemoglobin specific activities. Valine deficiency did decrease total hemoglobin synthesis by about $50 \%$ (Table IX). The addition of $\mathrm{C}^{12}$ leucine reduced the specific activity of both hemoglobins but did not change their ratio, indicating that the concentration of $\mathrm{C}^{14}$-leucine was not ratelimiting.

Omission of the ions potassium and magnesium from reticulocyte incubations on two occasions did not suppress total hemoglobin synthesis nor shift the hemoglobin specific activity ratios from their control values (Table IX).

\section{Discussion}

The factors responsible for the unequal amounts of allelic hemoglobins in individuals with heterozygous hemoglobin states are unknown. Available evidence suggests that the ratio of hemoglobins in the blood of such individuals is relatively constant and independent of environmental factors (12). Neel, Wells, and Itano (13) in a study of the hemoglobin proportions in seven families with the sickle cell trait found a highly significant difference between family mean values that was thought to be genetically determined, although the nature of the genetic system was not clear.

That the hemoglobin proportions in heterozygous states may reflect a fundamental genetic system gains further support from the work reported here. In every combination studied the ratio 
of specific activities of the two hemoglobins was nearly 1 , indicating that they were synthesized in vitro by marrow or reticulocytes, or both, in amounts proportional to that found in the circulation. Thus, the unequal amounts of the two circulating hemoglobins is due predominantly to an unequal synthetic rate rather than to selective cell removal. These findings are in agreement with those of Ranney and Kono (14), using $\mathrm{Fe}^{59}$ in vivo.

Several lines of evidence also indicate that the heterogenic hemoglobin synthesizing systems reported here are equally stable under a variety of conditions. The similarity in in vitro synthetic rates, whether bone marrow or reticulocytes and long or short incubation periods are used, implies that the relative synthetic rates are independent of the degree of cellular maturity. In addition, these systems were equally effective in competing for limited amounts of such essential metabolites as oxygen, iron, glucose, amino acids, magnesium, and potassium. This latter finding is in contrast to the situation in the whole blood and hematopoietic tissues of normal infants where there is a preferential synthesis of hemoglobin $\mathrm{F}$ over that of A under conditions of hypoxia $(15,16)$ or glucose lack (15).

Levere and Lichtman (17), in a study of four patients with sickle cell trait, found a higher specific activity in hemoglobin $\mathrm{S}$ as opposed to hemoglobin $\mathrm{A}$, using $\mathrm{Fe}^{59}$ in vivo. Similar results have been obtained in vitro with $\mathrm{C}^{14}$-leucine by Karpatkin (18) for the hemoglobin combination $\mathrm{S}$ and $\mathrm{F}$. In this instance selective destruction of cells rich in hemoglobin $\mathrm{S}$ is probably the most likely explanation, since the distribution of hemoglobin $F$ is known to be heterogenous $(19,20)$.

Once one allows that the proportions of circulating hemoglobin in allelic heterogenic states are the result of unequal synthetic rates, it is possible to make more fundamental hypotheses regarding the factors responsible for the difference. There may be a deficiency in the rate of synthesis of the messenger RNA for the mutant hemoglobin chain or a structural defect in the messenger. Such a defect could lead to instability, to faulty ribosomal attachment, or to the inability to initiate peptide chain formation. Other possible explanations are a difference in synthetic rates for the $\alpha$ and $\beta$ chains once initiated, or a difference in the rate of conversion of completed ribosomal peptide chains into finished hemoglobin. Studies are now in progress to investigate some of these possibilities.

\section{Summary}

The in vitro synthetic rate of heterogenous hemoglobins was studied in six patients, with both bone marrow and reticulocytes. Within experimental error, the ratio of circulating hemoglobins was an accurate reflection of synthetic rates. Variation of the incubation conditions and stimulation of erythropoiesis in the patients failed to alter the relative synthetic rates.

\section{Acknowledgments}

We are grateful to Dr. E. L. Conley, Johns Hopkins University Hospital, for the determination of $\mathrm{D}$ hemoglobin, and to Dr. William Bullock and Dr. Clifford Booker, Freedmen's Hospital, Washington, D. C., for allowing us to study their patients.

\section{References}

1. McCurdy, P. R. Erythrokinetics in abnormal hemoglobin syndromes. Blood 1962, 20, 686.

2. Jacob, F., and J. Monod. Genetic regulatory mechanisms in the synthesis of proteins. J. molec. Biol. 1961, 3, 318.

3. Jacob, F., and J. Monod. On the regulation of gene activity. Cold Spr. Harb. Symp. quant. Biol. 1961, 26, 193.

4. Spinco techn. Bull. 6095A, Spinco Division, Beckman Instruments, Palo Alto, Calif., November 1961.

5. Marder, V. J., and C. L. Conley. Electrophoresis of hemoglobins on agar gels. Frequency of hemoglobin D in a Negro population. Bull. Johns Hopk. Hosp. 1959, 105, 77.

6. Borsook, H., E. H. Fischer, and G. Keighley. Factors affecting protein synthesis in vitro in rabbit reticulocytes. J. biol. Chem. 1957, 229, 1059.

7. Key, J. A. Studies of erythrocytes, with special reference to reticulum, polychromatophilia, and mitochondria. Arch. intern. Med. 1921, 28, 511.

8. Huisman, T. H. J., E. A. Martis, and A. Dozy. Chromatography of hemoglobin types on carboxymethylcellulose. J. Lab. clin. Med. 1958, 52, 312.

9. Huisman, T. H. J., and C. A. Meyering. Studies on the heterogeneity of hemoglobin. I. The heterogeneity of different human hemoglobin types in carboxymethylcellulose and in Amberlite IRC-50 chromatography: qualitative aspects. Clin. chim. Acta 1960, 5, 103.

10. Lowry, O. H., N. J. Rosebrough, A. L. Farr, and R. J. Randall. Protein measurements with the Folin phenol reagent. J. biol. Chem. 1951, 193, 265. 
11. Schapira, Georges, D. Labie, J. Rosa, and J-C. Dreyfus. Evidence for a distinct fraction of hemoglobin, specifically associated with the younger erythrocytes. Biochem. biophys. Res. Commun. 1962, 9, 167.

12. Wells, I. C., and H. A. Itano. Ratio of sickle-cell anemia hemoglobin to normal hemoglobin in sicklemics. J. biol. Chem. 1951, 188, 65.

13. Neel, J. V., I. C. Wells, and H. A. Itano. Familial differences in the proportion of abnormal hemoglobin present in the sickle cell trait. J. clin. Invest. 1951, 30, 1120.

14. Ranney, H. M., and P. Kono. Studies of the incorporation of $\mathrm{Fe}^{58}$ into normal and abnormal hemoglobins. J. clin. Invest. 1959, 38, 508.

15. Allen, D. W., and J. H. Jandl. Factors influencing relative rates of synthesis of adult and fetal hemoglobin in vitro. J. clin. Invest. 1960, 39, 1107.
16. Thomas, E. D., H. L. Lochte, Jr., W. B. Greenough III, and M. Wales. In vitro synthesis of fœtal and adult hemoglobin by fœtal hæmatopoietic tissues. Nature (Lond.) 1960, 185, 396.

17. Levere, R. D., and H. C. Lichtman. Metabolism of heterogenic hemoglobins. $\mathrm{Fe}^{58}$ incorporation in sickle cell trait. Blood 1963, 22, 334.

18. Karpatkin, S. Globin synthesis in human reticulocytes. J. Lab. clin. Med. 1963, 62, 121.

19. Singer, K., and B. Fisher. Studies on abnormal hemoglobins. V. The distribution of type $\mathrm{S}$ (sickle cell) hemoglobin and type $\mathrm{F}$ (alkali resistant) hemoglobin within the red cell population in sickle cell anemia. Blood 1952, 7, 1216.

20. Shepard, M. K., D. J. Weatherall, and C. L. Conley. Semi-quantitative estimation of the distribution of fetal hemoglobin in red cell populations. Bull. Johns Hopk. Hosp. 1962, 110, 293. 